\title{
PENGEMBANGAN DESAIN PEMBELAJARAN MATEMATIKA SISWA SEKOLAH DASAR KELAS 6
}

\author{
EMA RAHMAWATI \\ emmarahma.er@gmail.com \\ HURI SUHENDRI \\ hurisuhendri@yahoo.co.id \\ Program Studi Pendidikan Matematika, Fakultas Teknik, Matematika dan IPA \\ Universitas Indraprasta PGRI
}

\begin{abstract}
Abstrak. Penelitian ini dilakukan untuk mengembangkan desain pembelajaran yang tepat dan sesuai bagi siswa Sekolah Dasar kelas 6. Jenis Penelitian yang digunakan adalah penelitian pengembangan dengan Model Pengembangan Instruksional (MPI). Penelitian ini dilakukan di Kecamatan Pancoranmas Depok dengan tiga sekolah yang dijadikan sebagai tempat penelitian yaitu, SDN Rangkapan Jaya, SDN Mampang 1, dan SDN Mampang 3. Penelitian ini dilakukan melalui tiga tahap yaitu: Tahap pertama dalam model MPI adalah tahap mengidentifikasi yang terdiri dari tiga langkah sebagai berikut: a. mengidentifikasi kebutuhan instruksional dan menulis tujuan instruksional umum; $b$. melakukan analisis instruksional; dan c. mengidentifikasi perilaku dan karakteristik awal peserta didik. Tahap kedua adalah tahap mengembangkan yang terdiri dari empat langkah sebagai berikut: a. menulis tujuan instruksional khusus; $b$. menyusun alat penilaian hasil belajar; c. Menyusun strategi instrusional; dan d. mengembangkan bahan instruksional. Tahap ketiga, mengevaluasi dan merevisi yang terdiri dari satu langkah yaitu menyusun desain dan melaksanakan evaluasi formatif yang termasuk di dalamnya kegiatan merevisi bahan instruksional. Hasil penelitian pengembangan ini adalah tersusunnya bahan ajar yang efektif bagi siswa Sekolah Dasar kelas 6 pada mata pelajaran Matematika.
\end{abstract}

Kata Kunci: Pengembangan, Desain Pembelajaran, Matematika SD.

\section{PENDAHULUAN}

Pendidikan merupakan upaya dasar untuk membentuk manusia yang berkualitas. Tidak dapat dipungkiri lagi manfaat yang akan diperoleh dari pendidikan yang berkualitas, diantaranya adalah berkembangnya ilmu pengetahuan dan teknologi. Berdasarkan hasil survei Badan Pusat Statistik (BPS, 2010), jumlah penduduk Indonesia pada tahun 2010 adalah sebanyak 237.641.326 jiwa. Hal tersebut menunjukkan bahwa Indonesia selain memiliki Sumber Daya Alam (SDA) yang berlimpah, juga memiliki Sumber Daya Manusia (SDM) yang banyak. Namun, SDM ini sangat disayangkan apabila tidak diiringi dengan pendidikan yang berkualitas yang dapat meningkatkan kualitas hidup masyarakat Indonesia.

Pemerintah Indonesia tentu selalu berupaya melakukan perbaikan di dunia pendidikan. Keseriusan dalam perbaikan pendidikan sesuai dengan tujuan pendidikan Indonesia yang telah tertuang dalam UU RI Nomor 20 Tahun 2003 tentang dasar, fungsi, dan tujuan pendidikan yaitu "Pendidikan nasional berfungsi mengembangkan kemampuan dan membentuk watak serta peradaban bangsa yang bermartabat dalam rangka mencerdaskan kehidupan bangsa, bertujuan untuk berkembangnya potensi peserta didik agar menjadi manusia yang beriman dan bertakwa kepada Tuhan Yang Maha Esa, berakhlak mulia, sehat, berilmu, cakap, kreatif, mandiri, dan menjadi warga Negara yang demokratis serta bertanggung jawab". 
Peserta didik merupakan salah satu komponen penting dalam dunia pendidikan. Dalam beberapa tingkat sekolah, salah satunya adalah Usia Sekolah Dasar (SD) yang merupakan usia antara 6-12 tahun. Menurut Syamsuddin (2009:103) perilaku kognitif pada usia Sekolah Dasar adalah, "Kemampuannya dalam proses berpikir untuk mengoperasikan kaidah-kaidah logika meskipun masih terikat dengan objek-objek yang bersifat konkret". Usia ini merupakan awal mula peserta didik banyak menerima materi baru yang berkaitan dengan logika seperti matematika. Menurut Abdurahman (2003:74), "Matematika adalah bahasa simbolis untuk mengekspresikan hubungan-hubungan kuantitafif dan keruangan, yang memudahkan manusia berpikir dalam memecahkan masalah dalam kehidupan sehari-harinya." Matematika masih dianggap sukar oleh sebagian peserta didik karena beberapa hal, diantaranya adalah karena banyaknya rumus yang digunakan maupun metode pembelajaran yang digunakan oleh guru kurang menyenangkan sehingga membuat peserta didik yang tidak suka pelajaran tersebut cepat merasa jenuh dan bosan. Hal tersebut membuat para guru resah karena mengakibatkan rendahnya hasil belajar matematika.

Kualitas guru juga dituntut untuk selalu kreatif dan inovatif dalam menyusun kegiatan pembelajaran. Mulai dari metode dan bahan ajar yang digunakan maupun alat pengukuran hasil belajar. Sebagai seorang guru, pengukuran kualitas guru tidak hanya berdasarkan pada penguasaan materi saja, tetapi guru juga dituntut agar lebih kreatif dan inovatif. Tujuan dari guru yang kreatif dan inovatif adalah guru diharapkan mampu membuat kegiatan pembelajaran yang lebih menyenangkan dan sesuai dengan tujuan pembelajaran yang diharapkan dengan menyesuaikan peserta didik yang diajarkannya.

Salah satu hal yang berpengaruh dalam pencapaian kompetensi mengajar adalah pembelajaran yang efektif. Pembelajaran yang efektif merupakan pembelajaran yang hasilnya sesuai dengan tujuan pembelajaran. Desain pembelajaran juga dibuat sedemikian rupa agar kegiatan pembelajaran dapat berjalan efektif. Menurut Hamzah dan Muhlisrarini (2014:309) "Desain Pembelajaran adalah kegiatan yang dilaksanakan untuk menentukan pendekatan pembelajaran apa yang paling baik dilaksanakan agar menimbulkan perubahan pengetahuan dan keterampilan pada peserta didik ke arah yang dikehendaki." Hal ini dapat diartikan bahwa salah satu hal yang berpengaruh dalam pembelajaran yang efektif adalah desain pembelajaran yang dibuat sesuai dengan kebutuhan peserta didik dan dilakukan demi tercapainya tujuan pembelajaran.

Ditinjau dari hal-hal yang telah diuraikan sebelumnya mengenai beberapa permasalahan yang terjadi pada siswa SD dengan matematika sebagai salah satu pelajaran yang cukup sulit. Maka, untuk menjawab permasalahan tersebut perlu dikaji bagaimana mengajarkan matematika khususnya bagi siswa SD kelas VI agar matematika lebih menarik dan mudah untuk di pahami. Untuk itu, peneliti ingin mengembangkan suatu desain pembelajaran dengan basis konseptual bagi siswa tingkat SD kelas VI dengan judul yang dibuat oleh peneliti adalah "Pengembangan Desain Pembelajaran Matematika Siswa SD kelas VI".

\section{TINJAUAN PUSTAKA}

\section{Pembelajaran Matematika Sekolah Dasar}

Matematika memang berkaitan erat dengan kehidupan sehari-hari, misalnya simbol kuantitas atau banyaknya suatu objek, pola-pola/bentuk benda, sistem siklus keteraturan suatu pola kehidupan dan lain-lain. Masalah membandingkan dua buah objek yang menghasilkan nilai sama, tidak sama, lebih besar atau lebih kecil merupakan contoh pola hubungan matematika yang lahir karena adanya realita praktis dalam kehidupan sehari-hari. Hubungan itu lalu diolah menjadi sebuah persamaan atau pertidaksamaan matematika. 
Dalam pembelajaran matematika tentu memiliki tujuan akhir yang ingin dicapai, salah satunya pada tingkatan Sekolah Dasar. Heruman (2012:47-48)menyatakan bahwa, Tujuan akhir pembelajaran matematika di SD ini yaitu agar siswa terampil dalam menggunakan berbagai konsep matematika dalam kehidupan sehari-hari. Berikut ini adalah pemaparan pembelajaran yang ditekankan pada konsep matematika:

1. Penanaman Konsep Dasar (Penanaman Konsep), yaitu pembelajaran suatu konsep baru matematika, ketika siswa belum pernah mempelajari konsep tersebut. Pembelajaran penanaman konsep dasar merupakan jembatan yang harus dapat menghubungkan kemampuan kognitif siswa yang konkret dengan konsep baru matematika yang abstrak.

2. Pemahaman Konsep, yaitu pembelajaran lanjutan dari pemahaman konsep, yang bertujuan agar siswa lebih memahami suatu konsep matematika.

3. Pembinaan keterampilan, yaitu pembelajaran lanjutan dari penanaman konsep dan pemahaman konsep. Pembelajaran pembinaan keterampilan bertujuan agar siswa lebih terampil dalam menggunakan berbagai konsep matematika.

Berdasarkan uraian sebelumnya, dapat disimpulkan bahwa pembelajaran matematika merupakan kegiatan yang berhubungan dengan pembelajaran eksak yang dapat berupa pola, bentuk, dan ruang, serta operasi perhitungan konsep-konsep abstrak yang dapat menimbulkan proses berpikir ilmiah dengan tujuan penguasaan kompetensi matematika SD mengenai konsep dasar matematika dan dapat diterapkan dalam kehidupan sehari-hari yang disusun secara bertahap agar siswa terampil dan sesuai dengan tujuan pendidikan nasional.

\section{Teori Pengembangan Desain Instruksional}

Desain instruksional merupakan pengembangan dalam menyusun suatu kegiatan pembelajaran secara sistemik untuk mencapai tujuan pembelajaran.Seels \& Richey (dalam Setyosari, 2013:277) berpendapat sebagai berikut, "Developmental research, as opposed to simple instructional development, has been defined as the systematic study of designing, developing and evaluating instructional programs, processes and products that must meet the criteria of internal consistency and effectiveness." Berdasarkan hal tersebut penelitian pengembangan sebagaimana dibedakan dengan pengembangan pembelajaran sederhana, didefinisikan sebagai kajian sistematik untuk merancang, mengembangkan, dan mengevaluasi program-program, proses, dan hasil pembelajaran yang harus memenuhi kriteria konsistensi dan keefektifan secara internal. Dari uraian tersebut dapat disimpulkan bahwa penelitian pengembangan merupakan kajian mengenai proses yang secara sistematik untuk merancang, mengembangkan, dan mengevaluasi pembelajaran yang melibatkan beberapa komponen yang bertujuan untuk mendesain sebuah desain pembelajaran yang efektif dan sesuai bagi peserta didik.

\section{Konsep Model Pengembangan Instruksional}

Pengembangan instruksional atau desain instruksional adalah proses yang sistematis dalam mencapai tujuan instrusional secara efektif dan efisien melalui pengidentifikasian masalah, pengembangan strategi dan bahan instruksional, serta pengevaluasian terhadap strategi dan bahan instruksional tersebut untuk menentukan halhal yang harus direvisi (Suparman, 2014:104). Definisi tersebut mengandung pengertian, yaitu:

1. Tujuan atau akhir desain instruksional adalah menghasilkan satu set produk instruksional yang efektif dan efisien dalam mencapai tujuan instruksional. Satu set produk ini disebut pula bahan instruksional atau sistem instruksional. 
2. Proses desain instruksional dimulai dengan mengidentifikasi masalah, dilanjutkan dengan mengembangkan strategi dan bahan instruksional, kemudian diakhiri dengan mengevaluasi efektivitas dan efisiensi bahan tersebut. Proses evaluasi disini termasuk revisi.

Menurut Maduarti, dkk (Suparman, 2014:104) menyatakan bahwa "Pengembangan pembelajaran, desain sistem pembelajaran, atau teknologi kinerja. Sebenarnya istilah tersebut dapat saja menunjuk hal yang sama, desain pembelajaran." Hal tersebut mengartikan bahwa desain instruksional mau desain sistem pembelajaran mengartikan hal yang sama yaitu desain pembelajaran.

\section{METODE}

Metode penelitian yang digunakan adalah metode penelitian pengembangan. Model pengembangan yang dipilih adalah pengembangan desain pembelajaran yang mengacu pada Model Pengembangan Instruksional (MPI) oleh Suparman (2014:131). Tahapan atau prosedur dalam menyusun suatu sistem instruksional adalah:Tahap pertama, mengidentifikasi yang terdiri dari tiga langkah sebagai berikut: mengidentifikasi kebutuhan instruksional dan menulis tujuan instruksional umum; dan melakukan analisis instruksional; dan mengidentifikasi perilaku dan karakteristik awal peserta didik.Tahap kedua, mengembangkan yang terdiri dari empat langkah sebagai berikut:menulis tujuan instruksional khusus;menyusun alat penilaian hasil belajar; menyusun strategi instrusional; dan mengembangkan bahan instruksional.Tahap ketiga, mengevaluasi dan merevisi yang terdiri dari satu langkah yaitu menyusun desain dan melaksanakan evaluasi formatif yang termasuk di dalamnya kegiatan merevisi bahan instruksional.

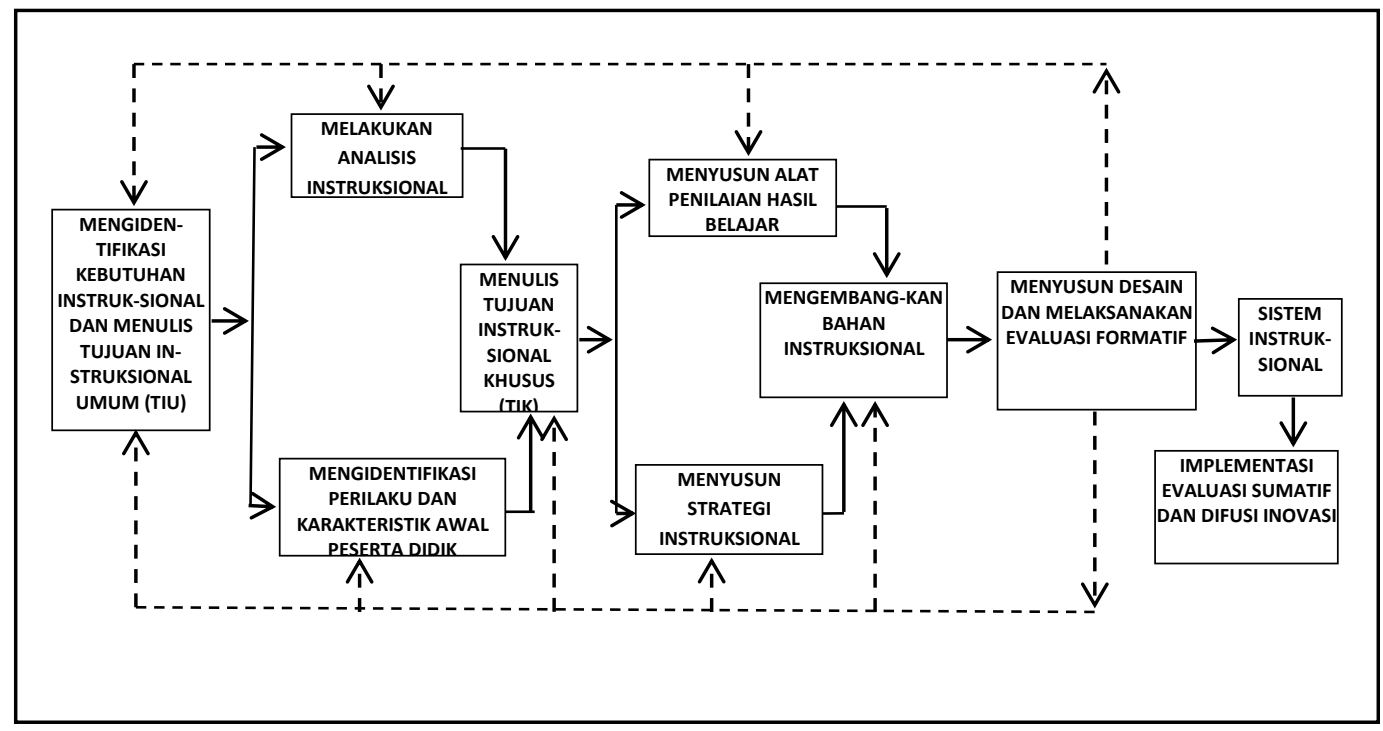

Gambar 1. Model Desain Instruksional Modern Atwi Suparman

Sumber: Desain Instruksional Modern Atwi Suparman (2014:105)

\section{HASIL DAN PEMBAHASAN}

Tahap pembuatan desain pembelajaran yang akhirnya menghasilkan bahan pembelajaran Matematika SD kelas 6 ini dilakukan oleh pendesain diadaptasi dari langkah-langkah model pengembangan instruksional yang dikembangkaan oleh M. Atwi Suparman. Adapun tahapan tersebut adalah sebagai berikut: 


\section{Analisis Kebutuhan dan Menentukan Tujuan Instruksional Umum}

Analisis kebutuhan peserta didik merupakan kegiatan awal pada proses pengembangan desain pembelajaran. Pada tahap analisis kebutuhan peneliti melakukan wawancara langsung kepada guru SD kelas 6 untuk mendapatkan informasi secara konkret mengenai karakteristik peserta didik serta kompetensi yang diharapkan dapat dicapai oleh peserta didik yang duduk di kelas 6 SD. Dalam wawancara tersebut beberapa dari narasumber mengatakan bahwa karakteristik peserta didik kelas 6 SD yakni sudah mempunyai sikap mandiri terutama dalam mengerjakan tugas, dan pola pikirnya sudah mulai berfikir secara abstrak. Selain itu saat pembelajaran peserta didik mudah bosan jika metode yang digunakan tidak tepat dan materi yang disampaikan terlalu sulit. Oleh karena itu sangat dibutuhkan sebuah pembelajaran dengan penyampaian menarik.

Dari kompetensi yang diharapkan dapat dicapai oleh peserta didik kelas 6 SD dirancang Tujuan Instruksional Umum (TIU) untuk menentukan kompetensikompetensi yang akan dicapai oleh peserta didik di kelas 6 SD sesuai dengan keinginan dan harapan dari para orang tua atau wali peserta didik kelas 6 SD. Tujuan instruksional umum inilah yang akan menjadi acuan untuk merangkai bahan pembelajaran yang sesuai dengan kompetensi-kompetensi yang diinginkan dapat dicapai oleh peserta didik. Pendesain menyusun satu TIU untuk keseluruhan proses pembelajaran Matematika SD kelas 6.

TIU yang disusun adalah "Jika diberikan soal latihan Matematika mengenai pelajaran Matematika Sekolah Dasar kelas 6, maka siswa kelas 6 Sekolah Dasar diharapkan mampu memahami dan mengerjakan dengan baik, dalam menyelesaikan soal-soal latihan maupun dalam pemecahan masalah berbentuk soal cerita dengan mandiri, cepat, dan minimal benar 80\%, yang meliputi materi kelas 6 Sekolah Dasar".

\section{Analisis Instruksional}

Pada tahap ini pendesain merangkai langkah-langkah atau tahapan-tahapan pencapaian kompetensi peserta didik kelas $6 \mathrm{SD}$, mulai dari yang termudah hingga tersulit. Tahapan-tahapan ini nantinya akan dimasukkan dalam bahan pembelajaran yang akan digunakan pada pembelajaran Matematika SD kelas 6. Hasil dari analisis instruksional adalah peta kompetensi yang menunjukkan susunan subkompetensi yang paling dasar sampai kompetensi yang paling tinggi seperti yang dirumuskan dalam TIU.

\section{Uraian Peta Kompetensi:}

1. Mampu menggunakan sifat-sifat operasi hitung termasuk operasi hitung campuran

2. Mampu menentukan faktor prima dan faktorisasi prima

3. Mampu menentukan Faktor Persekutuan Terbesar (FPB)

4. Mampu menentukan Faktor Persekutuan Terkecil (KPK)

5. Mampu menjumlahkan dan mengurangkan bilangan berpangkat tiga

6. Mampu mengalikan dan membagikan bilangan berpangkat tiga

7. Mampu menentukan akar pangkat tiga suatu bilangan kubik

8. Mampu menghitung akar pangkat tiga pada bilangan kubik

9. Mampu menyelesaikan masalah yang melibatkan operasi hitung termasuk penggunaan akar dan pangkat

10. Mampu menyederhanakan pecahan

11. Mampu mengurutkan pecahan

12. Mampu mengubah bentuk pecahan biasa ke bentuk pecahan desimal 
13. Mampu mengubah bentuk pecahan campuran menjadi pecahan desimal dan sebaliknya

14. Mampu menentukan nilai pecahan dari suatu bilangan atau kuantitas tertentu

15. Mampu melakukan operasi hitung yang melibatkan berbagai pecahan

16. Mampu menghitung perbandingan dan pecahan

17. Mampu menghitung perbandingan ukuran suhu

18. Mampu menghitung perbandingan dan skala

19. Mampu membaca denah berskala

20. Mampu menghitung keliling atau luas sebenarnya suatu daerah

21. Mampu menyebutkan satuan debit

22. Mampu menyebutkan satuan volume

23. Mampu menghitung hubungan antara jam, menit dan detik

24. Mampu menyelesaikan masalah yang berkaitan dengan satuan debit

25. Mampu menyebutkan sifat-sifat bangun datar

26. Mampu menghitung luas persegi

27. Mampu menghitung luas jajargenjang

28. Mampu menghitung luas trapesium

29. Mampu menghitung luas belah ketupat

30. Mampu menghitung luas layang-layang

31. Mampu menghitung luas segi banyak yang merupakan gabungan dari dua bangun datar sederhana

32. Mampu menghitung luas lingkaran

33. Mampu menghitung volume bangun ruang

34. Mampu menghitung volume prisma segitiga dan tabung lingkaran

35. Mampu membuat denah letak benda

36. Mampu membaca koordinat posisi sebuah benda

37. Mampu menentukan posisi titik dalam sistem koordinat Kartesius

38. Mampu menggambar bangun datar pada bidang koordinat

39. Menentukan pencerminan pada bidang koordinat

40. Mampu mengumpulkan dan membaca data

41. Mampu mengolah dan menyajikan data dalam bentuk tabel dan diagram

42. Mampu menyajikan data dalam tabel

43. Mampu menyajikan data dalam diagram

44. Mampu menafsirkan sajian data

45. Mampu mengurutkan data termasuk menentukan nilai tertinggi dan terendah

46. Mampu menghitung rata-rata hitung dan modus sekumpulan data.

Penggambaran uraian peta kompetensi ditunjukkan dalam gambar 2.

\section{Identifikasi Perilaku Peserta Didik SD Kelas 6}

Peneliti mengamati perilaku peserta didik yang dapat dilihat dari hasil analisis kebutuhan yang telah dilakukan pada pada awal kegiatan pengembangan desain instruksional. Hasil dari analisis kebutuhan tersebut penulis rangkum menjadi perilaku dan karakteristik yang ditunjukkan oleh peserta didik kelas 6 SD yang terbagi dalam tiga karakteristik, yaitu karakteristik dilihat dari segi fisik, karakteristik dilihat dari segi kecerdasan, dan karakteristik dilihat dari segi sosial-emosional. 


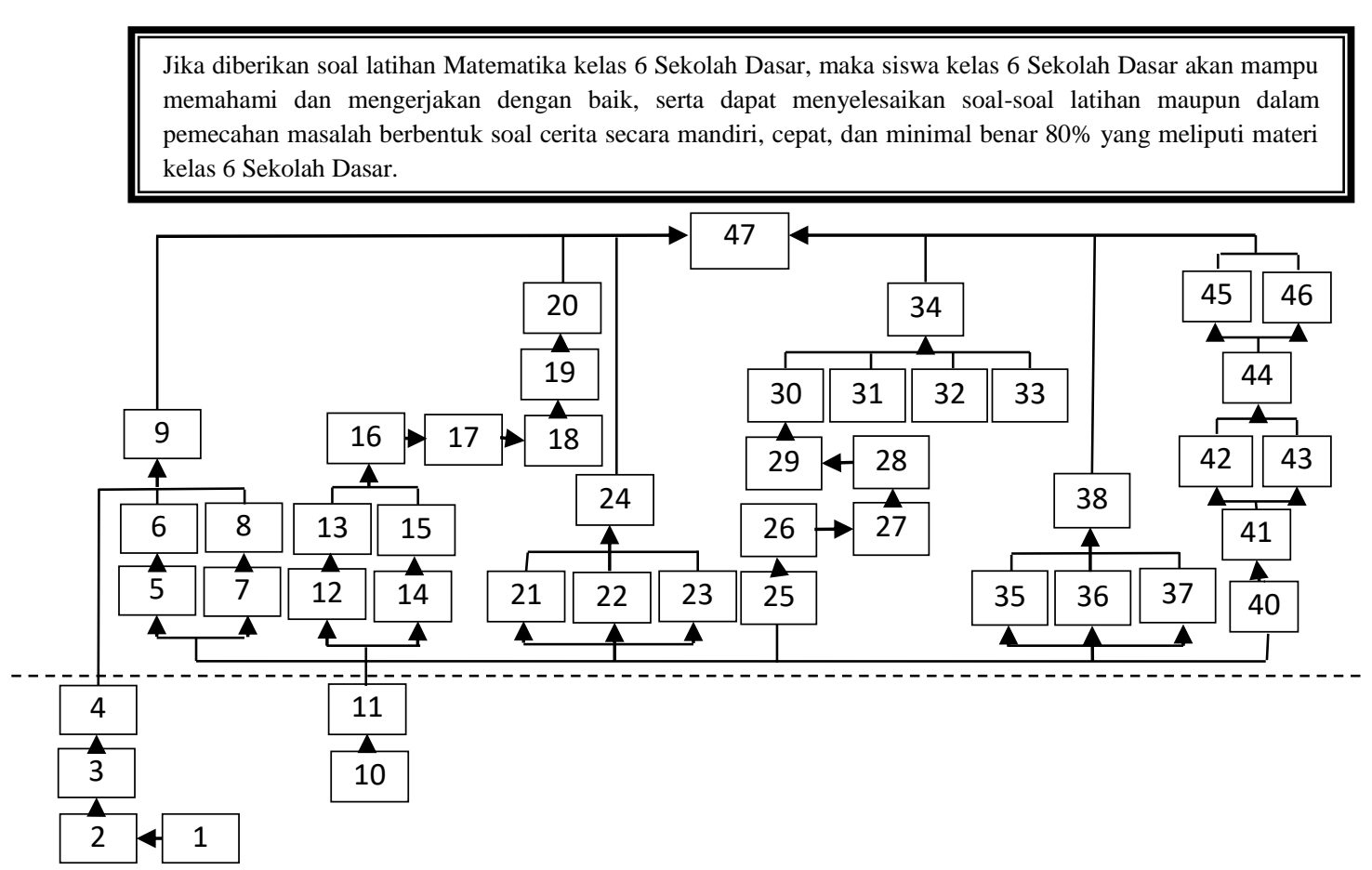

Gambar 2.Peta Kompetensi Pencapaian Hasil Belajar

\section{Menentukan Tujuan Instruksional Khusus (TIK)}

Tujuan instruksional khusus merupakan sebuah penjabaran dari TIU. Perumusan TIK ini sangat tergantung pada TIU. Oleh karena itu, TIU harus dimatangkan secara isi. Untuk proses penelitian ini pendesain menyusun enam butir TIK yang masing-masing TIK berkaitan dengan TIU yang telah dibuat sehingga mendapatkan komposisi yang pas dan sesuai dengan hasil yang diharapkan, yakni sebagai berikut.

a. Jika diberikan tes mengenai operasi hitung bilangan bulat, maka siswa Sekolah Dasar kelas 6 akan mampu menjawab dan menyelesaikan secara jelas dan terperinci, minimal benar $80 \%$.

b. Jika diberikan tes mengenai operasi hitung pecahan, maka siswa Sekolah Dasar kelas 6 akan mampu menjawab dan menyelesaikan secara jelas dan terperinci, minimal benar $80 \%$.

c. Jika diberikan tes mengenai volume per waktu, maka siswa Sekolah Dasar kelas 6 akan mampu menjawab dan menyelesaikan secara jelas dan terperinci, minimal benar $80 \%$.

d. Jika diberikan tes mengenai luas segi banyak sederhana, luas lingkaran, dan volume prisma segitiga maka siswa Sekolah Dasar kelas 6 akan mampu menjawab dan menyelesaikan secara jelas dan terperinci, minimal benar $80 \%$.

e. Jika diberikan tes mengenaisistem koordinat, maka siswa Sekolah Dasar kelas 6 akan mampu menjawab dan menyelesaikan secara jelas dan terperinci, minimal benar $80 \%$.

f. Jika diberikan tes mengenai mengumpulkan dan mengolah data, maka siswa Sekolah Dasar kelas 6 akan mampu menjawab dan menyelesaikan secara jelas dan terperinci, minimal benar $80 \%$. 


\section{Membuat Alat Penilaian Hasil Belajar}

Selanjutnya, penulis membuat rancangan instrumen penilaian. Instrumen penilaian ini yang nantinya akan dijadikan acuan dalam menilai hasil kompetensi pada akhir pembelajaran Matematika Kelas 6 SD. Rancangan instrumen yang dibuat oleh pendesain berupa butir-butir soal yang akan diujikan pada proses akhir pembelajaran. Butir-butir soal yang dibuat penulis mengacu pada tabel spesifikasi tes yang komperehensif. Tabel strategi yang dibuat memperhatikan TIU dan TIK yang telah dibuat sebelumnya. Tabel spesifikasi ini juga memuat indikator-indikator pencapaian siswa dalam pembelajaran Matematika SD kelas 6.

Dalam pembuatan tabel spesifikasi tes pendesain mengamati indikator-indikator umum yang telah disusun oleh Depdiknas untuk mata pelajaran Matematika SD kelas 6 yang kemudian disesuaikan dengan kompetensi-kompetensi yang diharapkan dicapai oleh peserta didik kelas 6 SD.

Tabel 1. Format Tabel Spesifikasi Tes yang Komprehensif Untuk Mata Pelajaran Matematika Sekolah Dasar Kelas Enam

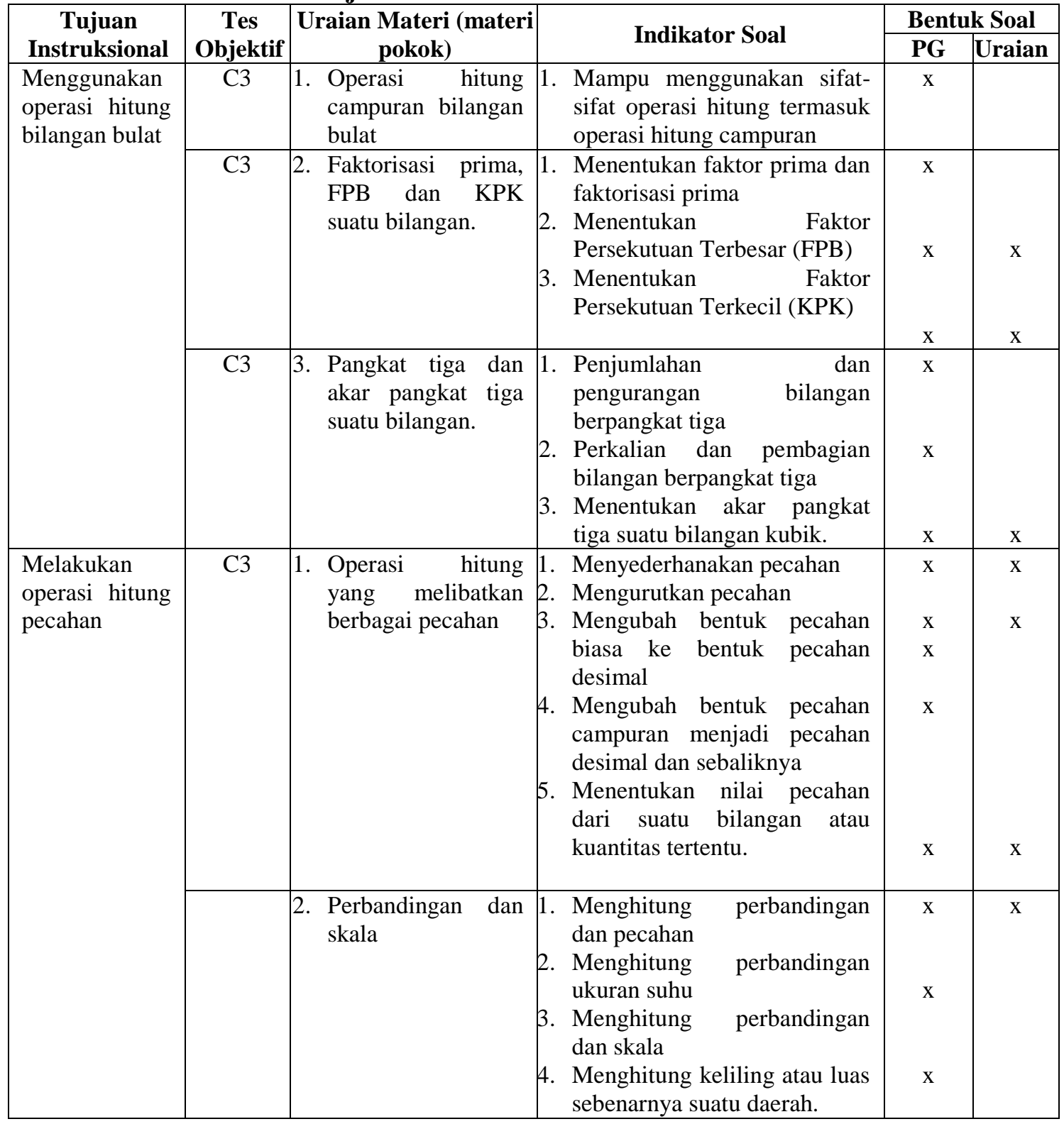




\begin{tabular}{|c|c|c|c|c|c|}
\hline & & & & $\mathrm{x}$ & $\mathrm{X}$ \\
\hline \multirow[t]{3}{*}{$\begin{array}{l}\text { Pengukuran } \\
\text { volume } \\
\text { per waktu }\end{array}$} & $\mathrm{C} 3$ & $\begin{array}{l}\text { 1. Hubungan antara } \\
\text { jam, menit dan } \\
\text { detik }\end{array}$ & $\begin{array}{l}\text { 1. Menghitung hubungan antara } \\
\text { jam, menit dan detik }\end{array}$ & $\mathrm{x}$ & \\
\hline & $\mathrm{C} 3$ & 2. Satuan volume & 1. Menghitung satuan volume & $\mathrm{x}$ & $\mathrm{x}$ \\
\hline & $\mathrm{C} 3$ & 3. Satuan debit & 1. Menghitung debit air & $\mathrm{x}$ & $\mathrm{x}$ \\
\hline \multirow[t]{3}{*}{$\begin{array}{l}\text { Luas segi } \\
\text { banyak } \\
\text { sederhana, } \\
\text { luas lingkaran, } \\
\text { dan volume } \\
\text { prisma } \\
\text { segitiga }\end{array}$} & $\mathrm{C} 3$ & $\begin{array}{l}\text { 1. Luas segi banyak } \\
\text { sederhana }\end{array}$ & $\begin{array}{ll}\text { 1. } & \text { Menghitung luas persegi } \\
& \text { panjang } \\
\text { 2. } & \text { Menghitung luas jajargenjang } \\
\text { 3. Menghitung luas trapesium } \\
\text { 4. } \text { Menghitung luas belah } \\
\text { ketupat } \\
\text { 5. Menghitung luas layang- } \\
\text { layang } \\
\text { 6. Menghitung luas segi banyak } \\
\text { yang merupakan gabungan } \\
\text { dari dua bangun datar } \\
\text { sederhana }\end{array}$ & $\mathrm{x}$ & $\mathrm{x}$ \\
\hline & $\mathrm{C} 3$ & 1. Luas lingkaran & $\begin{array}{l}\text { 1. Menghitung luas lingkaran } \\
\text { jika diketahui jari-jari atau } \\
\text { diameternya }\end{array}$ & $\mathrm{x}$ & \\
\hline & $\mathrm{C} 3$ & $\begin{array}{l}\text { 2. Volume prisma } \\
\text { segitiga dan tabung } \\
\text { lingkaran }\end{array}$ & $\begin{array}{l}\text { 1. Menghitung volume prisma } \\
\text { segitiga } \\
\text { 2. Menghitung volume tabung }\end{array}$ & $\mathrm{x}$ & $\mathrm{x}$ \\
\hline \multirow[t]{3}{*}{$\begin{array}{l}\text { Sistem } \\
\text { koordinat }\end{array}$} & $\mathrm{C} 3$ & $\begin{array}{l}\text { 1. Denah letak suatu } \\
\text { benda }\end{array}$ & 1. Membuat denah letak benda & & $\mathrm{x}$ \\
\hline & $\mathrm{C} 3$ & $\begin{array}{l}\text { 2. Koordinat posisi } \\
\text { sebuah benda }\end{array}$ & $\begin{array}{l}\text { 1. Menentukan posisi benda dari } \\
\text { denah atau peta }\end{array}$ & $\mathrm{x}$ & \\
\hline & $\mathrm{C} 3$ & $\begin{array}{l}\text { 3. Posisi titik dalam } \\
\text { sistem koordinat } \\
\text { Cartesius }\end{array}$ & $\begin{array}{l}\text { 1. Menentukan letak titik pada } \\
\text { koordinat } \\
\text { 2. Menggambar bangun datar } \\
\text { pada bidang koordinat } \\
\text { 3. Menentukan pencerminan } \\
\text { pada bidang koordinat }\end{array}$ & $\mathrm{x}$ & $\mathrm{x}$ \\
\hline \multirow[t]{3}{*}{$\begin{array}{l}\text { Mengumpulka } \\
\mathrm{n} \text { dan } \\
\text { mengolah data }\end{array}$} & $\mathrm{C} 3$ & 1. Mengurutkan data & $\begin{array}{l}\text { 1. } \begin{array}{l}\text { Mengurutkan data termasuk } \\
\text { menentukan nilai tertinggi } \\
\text { dan terendah }\end{array} \\
\end{array}$ & $\mathrm{x}$ & $\mathrm{x}$ \\
\hline & $\mathrm{C} 3$ & 2. $\begin{array}{l}\text { Mengolah dan } \\
\text { menyajikan data }\end{array}$ & $\begin{array}{l}\text { 1. Menyajikan data dalam } \\
\text { bentuk tabel } \\
\text { 2. Menghitung data dalam } \\
\text { bentuk diagram batang } \\
\text { 3. Menghitung data dalam } \\
\text { bentuk diagram lingkaran }\end{array}$ & $\mathrm{x}$ & $\mathrm{x}$ \\
\hline & $\mathrm{C} 3$ & 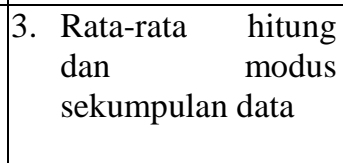 & $\begin{array}{l}\text { 1. } \begin{array}{l}\text { Menghitung nilai rata-rata } \\
\text { suatu data } \\
\text { 2. Menentukan nilai data yang } \\
\text { paling banyak keluar }\end{array}\end{array}$ & $\mathrm{x}$ & $\mathrm{X}$ \\
\hline
\end{tabular}

\section{Strategi Pembelajaran}

Strategi pembelajaran ini perlu dipersiapkan agar pembelajaran dapat berjalan secara fokus dan terarah pada pencapaian kompetensi-kompetensi peserta didik. Isi pembelajaran untuk setiap TIK yang telah dirancang sebelumnya bersama komponen lain seperti langkah-langkah kegiatan instruksional, metode, serta media dan alat 
instruksional akan tergambar dalam strategi instruksional. Dengan kata lain, daftar isi pembelajaran akan dibuat pendesain instruksional pada saat menyusun strategi instruksional ini.

Dalam penyusunan strategi penulis perlu menguasai teknik dan metode-metode pembelajaran serta media pembelajaran yang akan digunakan. Metode dan media pembelajaran ini yang akan membantu proses penyampaian materi ajar kepada peserta didik. Namun yang terpenting adalah penulis mengetahui dan memahami materi pembelajaran yang diajarkan di sekolah saat ini juga perlu diperhatikan.Oleh karena itu, kesesuaian antara metode dan media pembelajaran dengan materi pembelajaran itu sendiri akan menghasilkan sebuah pembelajaran bermakna bagi peserta didik.

Pendesain telah menyusun strategi pembelajaran ini pada setiap masing-masing TIK dengan dasar TIU. Strategi pembelajaran itu yang nantinya akan digunakan pada proses pembelajaran di kelas yang dikemas dengan adanya metode dan media pembelajaran hingga alokasi waktu yang ada telah terencana dengan baik. Pendesain mengalokasikan waktu selama 35 menit. Dengan strategi pembelajaran ini diharapkan agar setiap tahapan dan pembahasan dalam TIK dapat terlaksana untuk tercapainya kompetensi-kompetensi dalam TIU. Berikut diuraikan strategi pembelajaran dalam pengembangan desain pembelajaran matematika Sekolah Dasar kelas 6.

a. Mata pelajaran : Matematika SD Kelas 6

TIK No. 1:

Jika diberikan tes mengenai operasi hitung bilangan bulat, maka siswa kelas

6 Sekolah Dasar akan mampu menjawab dan menyelesaikan secara jelas dan terperinci, minimal benar $80 \%$.

Tabel 2.Strategi Pembelajaran TIK no.1

\begin{tabular}{|c|c|c|c|c|c|}
\hline \multirow{2}{*}{$\begin{array}{c}\text { URUTAN } \\
\text { KEGIATAN } \\
\text { PEMBELAJARAN } \\
1 \\
\end{array}$} & \multirow[t]{2}{*}{ GARIS BESAR ISI } & \multirow{2}{*}{$\begin{array}{c}\text { MET } \\
\text { ODE } \\
3 \\
\end{array}$} & \multirow{2}{*}{$\begin{array}{c}\text { MEDIA } \\
\text { \& ALAT } \\
4\end{array}$} & \multicolumn{2}{|c|}{$\begin{array}{l}\text { WAKTU } \\
\text { BELAJAR }\end{array}$} \\
\hline & & & & 5 & 6 \\
\hline \multicolumn{6}{|c|}{ TAHAP PENDAHULUAN } \\
\hline Deskripsi singkat isi & $\begin{array}{l}\text { Lingkup pelajaran ini adalah melakukan } \\
\text { operasi hitung bilangan bulat, baik } \\
\text { penjumlahan, pengurangan, perkalian, } \\
\text { dan pembagian }\end{array}$ & $\begin{array}{l}\text { Cera } \\
\text { mah }\end{array}$ & - & 3 & $\begin{array}{c}\text { Men } \\
\text { it }\end{array}$ \\
\hline $\begin{array}{l}\text { Relevansi dan } \\
\text { manfaat }\end{array}$ & $\begin{array}{l}\text { Operasi hitung bilangan bulat sangat } \\
\text { penting dan dapat digunakan untuk } \\
\text { mengoperasikan berbagai masalah } \\
\text { matematis maupun permasalahan sehari- } \\
\text { hari }\end{array}$ & $\begin{array}{l}\text { Cera } \\
\text { mah }\end{array}$ & Modul & 2 & $\begin{array}{c}\text { Men } \\
\text { it }\end{array}$ \\
\hline $\begin{array}{l}\text { Tujuan Instruksional } \\
\text { Khusus (TIK) }\end{array}$ & $\begin{array}{l}\text { Jika diberikan tes mengenai operasi } \\
\text { hitung bilangan bulat, maka siswa kelas } \\
6 \text { Sekolah Dasar akan mampu menjawab } \\
\text { dan menyelesaikan secara jelas dan } \\
\text { terperinci, minimal benar } 80 \%\end{array}$ & $\begin{array}{l}\text { Cera } \\
\text { mah }\end{array}$ & Modul & 3 & $\begin{array}{c}\text { Men } \\
\text { it }\end{array}$ \\
\hline \multicolumn{6}{|c|}{ TAHAP PENYAJIAN } \\
\hline Uraian & $\begin{array}{l}\text { - Menggunakan sifat-sifat operasi hitung } \\
\text { bilangan bulat } \\
\text { - Menentukan faktor prima dan } \\
\text { fakorisasi prima } \\
\text { - Menentukan FPB dan KPK } \\
\text { - Operasi hitung bilangan berpangkat } \\
\text { tiga } \\
\text { - Menentukan akar pangkat tiga suatu } \\
\text { bilangan kubik }\end{array}$ & $\begin{array}{l}\text { Cera } \\
\text { mah }\end{array}$ & Modul & 8 & $\begin{array}{l}\text { Men } \\
\text { it }\end{array}$ \\
\hline
\end{tabular}




\begin{tabular}{|c|c|c|c|c|c|}
\hline Contoh \& non contoh & $\begin{array}{l}\text { Contoh-contoh operasi hitung bilangan } \\
\text { bulat, menentukan FBB dan KPK, } \\
\text { menghitung bilangan pangkat tiga dalam } \\
\text { kehidupan sehari-hari. }\end{array}$ & $\begin{array}{l}\text { Cera } \\
\text { mah }\end{array}$ & Modul & 6 & $\begin{array}{c}\text { Men } \\
\text { it }\end{array}$ \\
\hline Latihan & $\begin{array}{l}\text { Siswa berlatih mengerjakan soal } \\
\text { berkaitan dengan operasi hitung } \\
\text { (penjumlahan, pengurangan, perkalian, } \\
\text { pembagian, pemfaktoran, bilangan } \\
\text { berpangkat,). }\end{array}$ & - & $\begin{array}{l}\text { Lembar } \\
\text { kerja } \\
\text { dalam } \\
\text { modul }\end{array}$ & 7 & $\begin{array}{c}\text { Men } \\
\text { it }\end{array}$ \\
\hline \multicolumn{6}{|l|}{ Rangkuman } \\
\hline \multirow{2}{*}{\multicolumn{6}{|c|}{$\begin{array}{l}\text { Glosarium } \\
\text { TAHAP P }\end{array}$}} \\
\hline & & & & & \\
\hline $\begin{array}{l}\text { Tes Formatif dan } \\
\text { Umpan Balik }\end{array}$ & $\begin{array}{l}\text { Mengidentifikasi kesulitan yang masih } \\
\text { dirasakan oleh siswa sehubungan dengan } \\
\text { materi yang telah dipelajari }\end{array}$ & $\begin{array}{l}\text { Cera } \\
\text { mah }\end{array}$ & - & 3 & $\begin{array}{c}\text { Men } \\
\text { it }\end{array}$ \\
\hline Tindak Lanjut & $\begin{array}{l}\text { - Penjelasan kembali bagian-bagian } \\
\text { yang belum dimengerti } \\
\text { - Penugasan untuk menghitung } \\
\text { penjumlahan, pengurangan, perkalian } \\
\text { dan pembagian bilangan } \\
\text { bulat,menentukan KPK dan FPB, dan } \\
\text { pangkat tiga suatu bilangan. }\end{array}$ & $\begin{array}{l}\text { Cera } \\
\text { mah }\end{array}$ & $\begin{array}{l}\text { Lembar } \\
\text { kerja } \\
\text { dalam } \\
\text { modul }\end{array}$ & 3 & $\begin{array}{c}\text { Men } \\
\text { it }\end{array}$ \\
\hline \multicolumn{4}{|l|}{ Jumlah waktu } & 35 & $\begin{array}{c}\text { men } \\
\text { it }\end{array}$ \\
\hline
\end{tabular}

\section{Mengembangkan Bahan Instruksional}

Bahan pembelajaran merupakan sebuah produk yang akan dihasilkan dari proses pengembangan desain pembelajaran Matematika Sekolah Dasar kelas 6. Bahan instruksional inilah yang isinya memuat materi-materi dan kegiatan lainnya berupa latihan-latihan sebagai penunjang untuk tercapainya kompetensi-kompetensi peserta didik.Dari segi muatan isi, penulis menyusun bahan instruksional ini dengan memperhatikan antara TIU dan TIK hingga strategi yang telah disusun sebelumnya. Selain itu penulis mengambil beberapa buku-buku sekolah guna dijadikan referensi dalam pembuatan bahan instruksional. Dari segi desain atau tampilan bahan instruksional, penulis membuat semenarik mungkin dengan penggunaan tema atau background berwarna disertai gambar-gambar menarik. Hal ini bertujuan agar peserta didik tidak merasa bosan dan jenuh saat proses pembelajaran berlangsung.

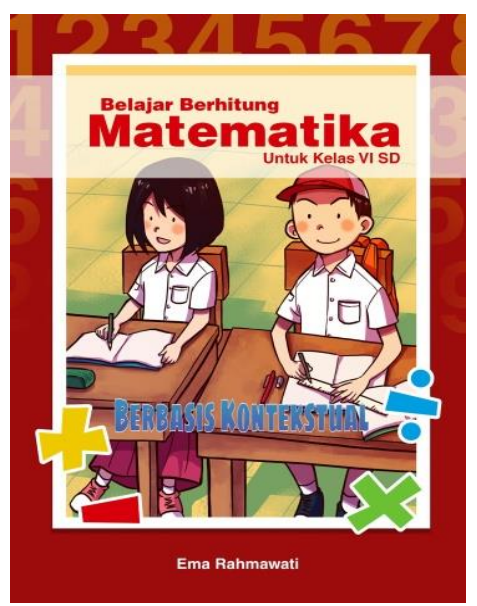

Gambar 3.Sampul Depan Buku yang telah Peneliti Buat 


\section{Melakukan Evaluasi Formatif}

Evaluasi formatif bertujuan untuk menentukan apa yang harus ditingkatkan atau direvisi agar produk lebih sistematis, efektif, dan efisien. Idealnya, pendesain instruksional melakukan empat tahapan evaluasi formatif, yaitu review oleh ahli di luar tim pendesain instruksional, evaluasi satu-satu, evaluasi kelompok kecil dan uji coba lapangan.

Evaluasi formatif yang dilakukan pendesain yaitu review oleh para ahli di luar tim pendesain instruksional. Hal ini dimaksudkan untuk memperoleh pendapat dari pihak lain, sesama ahli tentang bagaimana aspek ketepatan konten menurut ahli bidang studi, memadai atau tidaknya strategi instruksional dari pendesain bidang studi, dan desain fisik dari ahli media.

Kualitas bahan instruksional Matematika SD kelas 6 didasarkan pada penilaian evaluasi formatif yaitu satu dosen matematika,satu dosen bahasa, satu dosen ahli teknik pendidikan dan tiga orang guru matematika. Komponen penilaian terdiri dari komponen kelayakan isi, komponen kelayakan kegiatan instruksional, dan komponen fisik bahan instruksional. Selain bahan instruksional yang di evaluasi, seluruh kegiatan proses instruksional ini juga di evaluasi. Beberapa poin yang di evaluasi yakni sebagai berikut:

1) Kebenaran dan kemutakhiran isi menurut bidang ilmu dan relevansi dengan tujuan instruksional

2) Kebenaran istilah-istilah teknis

3) Ketepatan perumusan TIU

4) Memadai atau tidaknya analisis instruksional

5) Relevansi TIK dengan TIU

6) Ketepatan perumusan TIK

7) Relevansi tes dengan tujuan instruksional

8) Kualitas teknis penulisan tes

9) Relevansi strategi instruksional termasuk isi dengan tujuan instruksional

10) Relevansi produk atau bahan instruksional dengan tes dan tujuan instruksional

11) Kualitas teknis produk instruksional

Dari beberapa masukan validator dan dilakukan beberapa kali revisi, bahan instruksional yang diadaptasi dari Model Pengembangan Instruksional M. Atwi Suparman diharapkan mampu memfasilitasi pencapaian kompetensi-kompetensi peserta didik kelas $6 \mathrm{SD}$ dalam pemecahan masalah matematis. Hasil dari pengembangan desain instruksional ini adalah produk berupa bahan ajar yang memuat materi SD kelas 6. Bahan ajar ini dilengkapi dengan Tujuan Instruksional Umum (TIU), Tujuan Instruksional Khusus (TIK), indikator pencapaian kompetensi, peta konsep, latihan-latihan yang mengaplikasikan metode pembelajaran dari strategi pembelajaran kooperatif, serta dilengkapi dengan uji kemampuan dan latihan akhir tahun untuk mengukur sejauh mana pencapaian kompetensi peserta didik.

Isi materinya terdiri dari 6 bab, yaitu: Operasi hitung bilangan bulat; Operasi hitung pecahan; Pengukuran volume per waktu; Luas segi banyak sederhana, luas lingkaran, dan volume prisma segitiga; Sistem koordinat; dan Mengumpulkan dan mengolah data. Dalam penyampaian materi penulis menggunakan kata-kata yang mudah dimengerti oleh peserta didik SD kelas 6. Selain itu, agar kegiatan pembelajaran tidak membosankan penulis menerapkan metode-metode pembelajaran dari strategi pembelajaran kooperatif dalam mengerjakan soal-soal dan cara mengerjakannya, dimana strategi pembelajaran kooperatif tersebut memang disesuaikan dengan karakteristik peserta didik SD kelas 6 


\section{PENUTUP}

\section{Simpulan}

Bahan ajar Matematika Sekolah Dasar kelas 6 dalam desain instruksional ini telah dikembangkan dengan model pengembangan instruksional M.Atwi Suparman melalui tahap pendahuluan, analisis dan pengembangan prototype, serta melaksanakan evaluasi formatif. Pada tahap pendahuluan terdiri dari mengidentifiksi kebutuhan instruksional dan menulis tujuan instruksional umum, melakukan analisis instruksional, serta mengidentifikasi perilaku dan karakteristik awal peserta didik. Pada tahap berikutnya, yakni analisis dan pengembangan prototype terdiri dari menulis tujuan instruksional umum, menulis alat penilaian hasil belajar, menyusun strategi instruksional, dan mengembangkan bahan instruksional. Tahap terakhir yaitu melaksanakan evaluasi formatif penelaahan oleh pakar dan revisi. Penilaian kualitas bahan ajar dilaksanakan pada tahap evaluasi formatif oleh tiga ahli yang terdiri dari ahli materi, ahli pendesain instruksional, dan ahli bahasa. Hasil penilaian dari ahli tersebut adalah bahan ajar instruksional yang telah terstruktur dan terprogram dengan kualitas yang baik.

\section{Saran}

Berdasarkan simpulan dan implikasi penelitian, ada beberapa saran terkait yang dapat penulis sampaikan pada penelitian ini, yaitu:

1. Dalam mengembangkan bahan instruksional harus sesuai dengan karakteristik peserta didik

2. Bahan Ajar Matematika Sekolah Dasar Kelas 6 dalam desain instruksional ini dapat dikembangkan kembali dalam bentuk software macromedia flash agar pembelajaran dengan menggunakan media tersebut lebih menarik dan menyenangkan.

3. Strategi pembelajaran yang masih menggunakan metode konvensional lebih baik diubah dengan lebih kreatif dan inovatif agar peserta didik tidak mudah jenuh dalam mengikuti kegiatan pembelajaran.

\section{DAFTAR PUSTAKA}

Abdurahman, Mulyono. 2003. Pendidikan Bagi Anak Berkesulitan Belajar. Jakarta: PT. Rineka Cipta

Badan Pusat Statistik. 2010. Hasil Sensus Penduduk 2010.http://bps.go.id. Diakses 30 April 2016.

Hamzah dan Muhlisrarini. 2014. Perencanaan Dan Strategi Pembelajaran Matematika. Jakarta: PT Raja Grafindo Persada.

Heruman. 2012. Model Pembelajaran Matematika Di Sekolah Dasar. 2012. Bandung: PT Remaja Rosdakarya.

Setyosari, Punaji. 2013. Metode Penelitian Dan Pengembangan. Jakarta: KENCANA. Suparman, Atwi. 2014. Desain Instruksional Modern Panduan ParaPengajar \& Inovator Pendidikan. Jakarta: Erlangga

Syamsuddin, Makmun Abin. 2009. Psikologi Kependidikan. Bandung: PT. Remaja Rosdakarya.

Undang-undang RI Nomor 20 Tahun 2003 Tentang Sistem Pendidikan Nasional. 